\title{
Changes in connective tissue in patients with pelvic organ prolapse - a review of the current literature
}

\author{
M. H. Kerkhof • L. Hendriks • H. A. M. Brölmann
}

Received: 24 June 2008 / Accepted: 22 September 2008 / Published online: 15 October 2008

(C) The Author(s) 2008. This article is published with open access at Springerlink.com

\begin{abstract}
Little is known about the pathophysiology of pelvic organ prolapse (POP). In 1996, Jackson presented a hypothesis on pelvic floor connective tissue that tried to explain the development of POP on a molecular level. The objective of this review is to test the hypothesis against recent literature. The method used was a review of literature. The association between POP and connective tissue metabolism is well established. However, the causality of this association is unclear. The characteristics of the pelvic floor connective tissue of POP patients relate to tissue repair. To resolve the question of cause and effect, the role of fibroblasts in producing the extracellular matrix should be clarified. With these data, the use of autologous or allogenic stem cells in the treatment of POP may come in sight. Recent literature supports the hypothesis of Jackson but does not resolve long-standing questions on the aetiology of POP.
\end{abstract}

Keywords Connective tissue - Extracellular matrix · Fibroblast $\cdot$ Pelvic floor $\cdot$ Prolapse

\footnotetext{
M. H. Kerkhof $(\bowtie)$

Kennemer Gasthuis Haarlem, Boerhaavelaan 22,

2035 RC Haarlem, The Netherlands

e-mail: mhkerkhof@freeler.nl

L. Hendriks · H. A. M. Brölmann

Vrije Universiteit medisch centrum,

De Boelelaan 1117,

1181HV Amsterdam, The Netherlands

L. Hendriks

e-mail: linhendriks@gmail.com

H. A. M. Brölmann

e-mail: h.brolmann@vumc.nl
}

\author{
Abbreviations \\ POP Pelvic organ prolapse \\ ATFP Arcus tendineus fasciae pelvis \\ ECM Extracellular matrix \\ USL Uterosacral ligaments \\ UsR Uterosacral ligament resilience \\ AGE Advanced glycated endproduct \\ MMP Matrix metalloproteinases \\ TIMP Tissue-derived inhibitors of metalloproteinases \\ LOX Lysyl oxidases \\ ET-1 Endothelin-1 \\ ER Estrogen receptor
}

\section{Introduction}

Pelvic organ prolapse (POP) is a global health problem, affecting adult women of all ages. It decreases their quality of life considerably [1-3]. POP is one of the most common reasons for gynaecological surgery in women after the fertile period. The failure rate is relatively high: An estimated $30 \%$ of women require re-operation [3]. Despite the high incidence of POP, little is known about the underlying pathophysiolgy of POP. Multiparity, old age, overweight, chronic straining and obstructive lung diseases are the most important risk factors $[4,5]$. However, also nulliparous women without any risk factors may develop POP. Therefore, a genetic predisposition may play a role as well [6-8]. When a mother has POP, the relative risk for the daughter of developing POP is 3.2. With a sister's positive medical history, this relative risk is 2.4 [9]. In combination with the finding that women with joint hypermobility have a significant higher prevalence of POP [10], it is hypothesised that a connective tissue factor is involved. 
In 1996, Jackson found that patients with a descent of the cervix to, or beyond the introitus, with associated cystocele, have a reduced collagen content, with a relatively high content of immature collagen cross-links compared to non-POP patients. This newly formed collagen is degraded more easily than older glycated material, resulting in a decrease of collagen content, leaving behind glycated collagen resulting in tissue with an impaired mechanical strength [11]. He also found an increase in metalloproteinase activity, suggesting an increased degradation of collagen in patients with POP. He concludes that the bulk of this deficient glycated old collagen, which is brittle and susceptible to rupture, is an important aetiologic factor in POP. Up till now, the connective tissue metabolism is assessed by biochemical evaluation. The role of fibroblasts that produce the molecules in the extracellular matrix, such as collagen and elastin, needs further elucidation. It has been suggested to treat POP with autologous stem cells [12]. These stem cells are stimulated to differentiate into fibroblast-like cells producing collagen and can be seeded on biocompatible material serving as a "bioactive scaffold". Before doing so, it is important to know if there is a defective collagen metabolism at all caused by an error in the fibroblast, and if so, if this is the result of a genetic or an acquired defect.

The objective of this review is to summarise our current understanding of changes in pelvic floor connective tissue in women with POP compared to women without POP. Studies concerning collagen metabolism in POP patients will be reviewed in the light of Jackson's hypothesis [13]. Based on subsequent literature, we will test this hypothesis against the latest facts. We will also make recommendations for future research. Ultimately, this knowledge may lead to preventive measures that could eliminate or delay the onset of prolapse and improve surgical treatment.

\section{Materials and methods}

The primary investigator and a clinical librarian searched the computerised databases MEDLINE and EMBASE up to 2008 , using terms such as "prolapse", "uterine prolapse", "cystocele", "rectocele", "pelvic organ support", "urinary incontinence", "connective tissue", "collagen", "hydroxyproline", "tropocollagen", "procollagen", "protocollagen", "extracellular matrix", "elastic tissue", "supportive tissue", "extracellular matrix proteins", "tissue inhibitor of metalloproteinases", "matrix metalloproteinases" and "collagenases". Not only free text terms but also Mesh terms were used. Only data published in full article form were included. Additionally, articles were obtained by reviewing reference lists of pertinent studies and reviews. Also, the Web of Science was searched for "citing papers" and "related articles". No articles written in languages other than English provided additional information.

\section{Anatomy and function of the vagina and supportive connective tissue}

The pelvic floor is the caudal confinement of the abdominal cavity, which contains the abdominal viscera. In the days when we were quadrupeds, the pelvic floor was supposed to wag the tail. Now, in erect humans, its function is to prevent the viscera from "falling out" and to enable sexual intercourse, birth and the deliberate passage of stools and urine. In case of a sudden increase of the abdominal pressure, e.g. during coughing, all the muscles confining the abdominal cavity will contract. They create a counterforce that maintains the bodily shape. The pelvic floor is lifted at contraction and the genital hiatus is closed, preventing not only the uterus and vagina but also the intestines from being pushed out. If the pelvic floor has weakened, e.g. during vaginal delivery, the hiatus may not fully close anymore at contraction of the levator muscle. The counterforce will not come into effect, and POP may occur.

A second line of defence is the vaginal support from the connective tissue attachments between the vagina and the pelvic sidewall and levator ani muscles. The supportive connective tissue is a continuous, interdependent sheet, which supports the vagina and the pelvic organs. Based on post mortem data, Delancey [14] described pelvic floor support at three levels. Level I includes the uterosacral ligaments. The middle part of the vagina (endopelvic fascia) is attached laterally to the arcus tendineus fasciae pelvis (ATFP) and the superior fascia of the levator ani muscles (level II). In the lower third of the vagina, the wall is directly attached to the surrounding structures, the perineal membrane and the perineal body (level III). This suspensory system prevents the uterus and vagina from falling out while the hiatus is opened. If the resilience of the connective tissue decreases with age, the ligaments may finally give way, and POP may develop [15].

\section{Pelvic floor connective tissue}

The vaginal wall is composed of four layers: a superficial layer of stratified squamous epithelium, a subepithelial dense connective tissue layer, composed primarily of collagen and elastin, a layer of smooth muscle referred to as the muscularis and an adventitia, which is composed of loose connective tissue. The vaginal subepithelium and muscularis together form a fibromuscular layer beneath the vaginal epithelium, providing longitudinal and central support.

The connective tissue underlying the vagina contains relatively few cells: Beside fat cells and mast cells, mainly 
fibroblasts are found, producing components of the extracellular matrix (ECM). The ECM contains fibrillar components (collagen and elastin) embedded in a non-fibrillar ground substance. This ground substance consists of noncollagenous glycoproteins, proteoglycans and hyaluronan. In addition, with the exception of the ATFP, these tissues contain a significant amount of smooth muscle cells [16]. The fibrillar component is thought to contribute the most to the biomechanical behaviour of these tissues. The quantity and quality of collagen and elastin are regulated through a precise equilibrium between synthesis, maturation and degradation. This process results in a dynamic process of constant remodelling.

\section{Collagen synthesis}

In 1954, Ramachandran and Kartha [17] discovered the triple helical structure of collagen. In the endoplasmatic reticulum, $\alpha$ chains are formed, followed by posttranslational modifications of proline and lysine residues. Each collagen molecule is made of a precise combination of three $\alpha$-polypeptide chains. Depending on the collagen type, the three $\alpha$-polypeptide chains vary. The three helices are twisted together into a triple helix, stabilised by numerous hydrogen bonds. There is some covalent cross-linking within the triple helices and a variable amount of covalent crosslinking between collagen helices, resulting in tissue-residing collagen of different maturity.

Once the triple helix called procollagen is formed intracellularly, it is secreted into the extracellular space. Tropocollagen molecules are formed by the action of carboxy-terminal and amino-terminal peptidases. The tropocollagen molecules undergo self-assembly into collagen fibrils, which in turn associate to form fibres and fibre bundles (Fig. 1). The shape and behaviour of a tissue are determined in part by the correct positioning of collagen fibrils within a fibre and fibres within a matrix.

There are 28 types of collagen. The fibrillar collagens I, III and V, present in the vagina, and its supportive tissues are thought to be the principal determinants of soft tissue strength. Collagen I fibres are universally present and are flexible and offer great resistance to tension. Collagen III is predominant in tissues that require increased flexibility and distension and that are subject to periodic stress [18]. It is the primary collagen subtype in vagina and supportive tissues. Collagen III is the major collagen in skin at birth before it is replaced by collagen I later in life. Both type I and type III are found in granulation tissue during wound repair $[19,20]$. Collagen $\mathrm{V}$ is of minor quantitative importance. It forms small fibres with very low tensile strength and has
Fig. 1 Collagen biosynthesis. Collagen is synthesised as prepro- $\alpha$-chains (1). Following translocation into the rough endoplasmic reticulum, the signal peptides are removed, and the individual procollagen $\alpha$-chains will associate through the $\mathrm{C}$ propeptides. After multiple steps of posttranslational modifications, which include the hydroxylation of specific lysine (Lys) and proline (Pro) residues as well as the glycosylation of hydroxylysyl residues (2), the triple helix propagates from the $\mathrm{C}$ - to N-terminus. The procollagen is excreted and is converted extracellularly into collagen by cleaving the propeptides (3). Subsequently, collagen molecules assembly into ordered fibrils (4), which are finally stabilised by the formation of inter- and/or intramolecular cross-links (5)
1

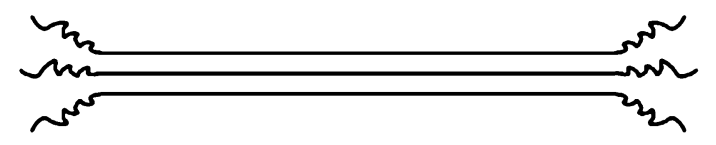

2

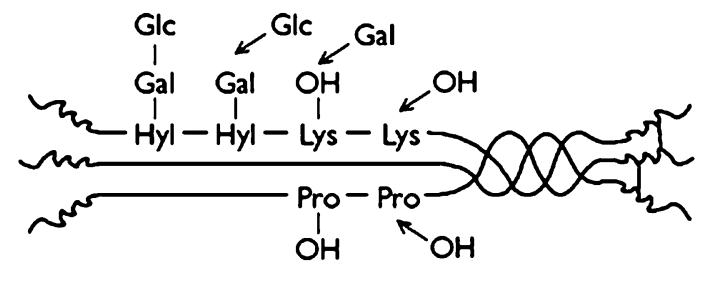

Intracellular

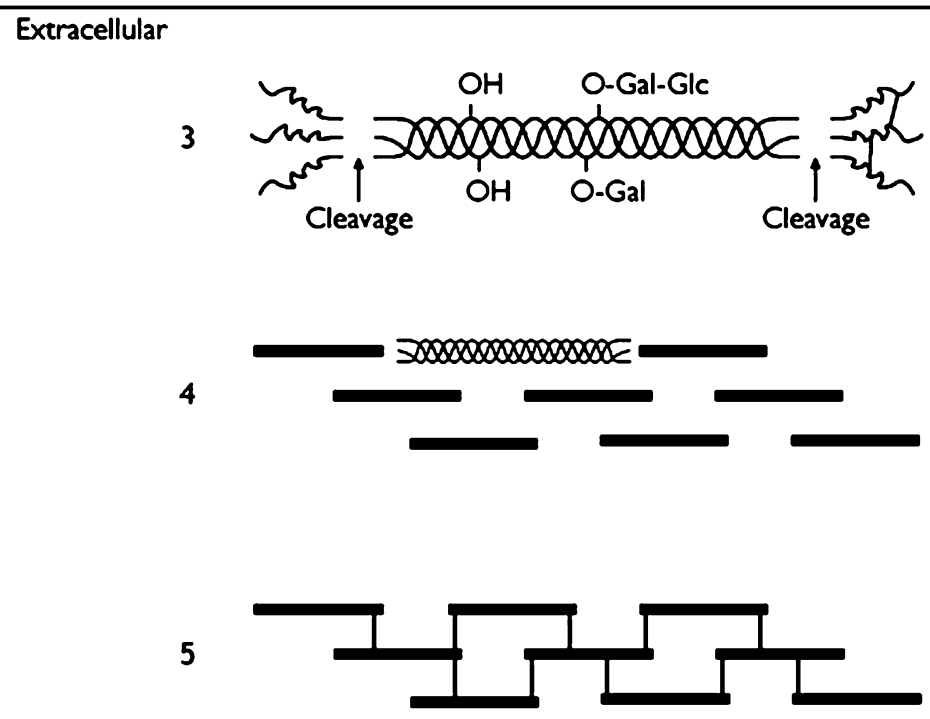


been found to be also important in wound healing and fibrillogenesis [21]. The role of collagen $\mathrm{V}$ in the vagina and supportive tissue has not been elucidated yet.

Collagen I copolymerises with collagen III and V to form fibrils with controlled diameters. These fibrils influence the biomechanical characteristics of a given tissue [21]. An increase in collagen III and V decreases the mechanical strength of connective tissue by decreasing fibre size [22]. It is generally agreed that a higher I/III ratio in the ligament is indicative of greater strength, whereas a lower ratio may result in tissue laxity.

Maturation and physiological ageing of collagen

Age is a risk factor for POP. In the POSST study, there was a $10 \%$ increased risk of POP for each decade of life [23]. Olsen et al. [3] found that the cumulative incidence of primary operation for POP and incontinence increased from $0.1 \%$ in the age group $20-29$ up to $11.1 \%$ in the age group 70-79.

Reay Jones et al. [15] assessed the Uterosacral ligament Resilience (UsR) by tensiometry in patients with and without POP to determine whether it influenced uterine or pelvic floor mobility or whether it varied with age, vaginal delivery, menopause or histological variations in the ligament. $\mathrm{He}$ found that the UsR was significantly reduced $(P=0.02)$ in symptomatic POP. There was a significant decrease in UsR with menopause $(P=0.009)$ and older age $(P=0.005)$, suggesting that where pelvic floor muscles are weakened, a decrease in pelvic connective tissue resilience - related to the age and menopause - may facilitate progression to symptomatic POP.

Two mechanisms of maturation of collagen have been identified. The first involves the enzymatically controlled lysine aldehyde cross-links. The initial enzymatic controlled divalent cross-links dehydro-hydroxy lysinonorleucine and hydroxylysinoketo-norleucine are converted to stable trivalent cross-links, histidino-hydroxylysinonorleucine and hydroxylysyl-pyridinoline, as the tissue matures [24]. The relative proportion of the initial divalent cross-links to mature cross-links enables an assessment of the maturation of the tissue. The mechanism of creating strength of the collagen by interfibrillar cross-links is currently under investigation.

Secondly, the mature, slowly metabolising collagen is susceptible to the so-called non-enzymatic cross-linking, also known as glycation or Maillard reaction. It involves the fairly random addition of glucose to the collagen, as the turnover of collagen is generally rather low. The products of this glycation ultimately react further to form intermolecular cross-links. It has been well established that these advanced glycated endproducts (AGEs) of collagen accumulate with age (Fig. 2). This mechanism is the major cause of substantial dysfunction of the collagenous tissues and is responsible for the complications of connective tissues seen at older age. The "overmature" collagen is stiffer and therefore more fragile than the collagen that exhibit only enzymatic cross-links [24, 25]. The glycation of other proteins involves the same mechanisms. But the long biological half-life of collagen ensures that it plays an important role in ageing. The nature and relative importance of the cross-links formed in vivo, in comparison to those reported formed in vitro with model compounds, still needs to be established as the structure of only a few AGEs has been established.

With the knowledge of changes of collagen with age, more research of POP, especially in young women, will elucidate the underlying pathophysiology of the disease.

\section{Degradation of collagen}

The balance between synthesis and degradation of collagen is important for maintaining tissue integrity and tensile strength during continuous tissue remodelling. Degradation depends upon the combined activity of matrix metalloproteinases (MMP) and their regulation of release, activation or sequestration of growth factors, growth factor

1

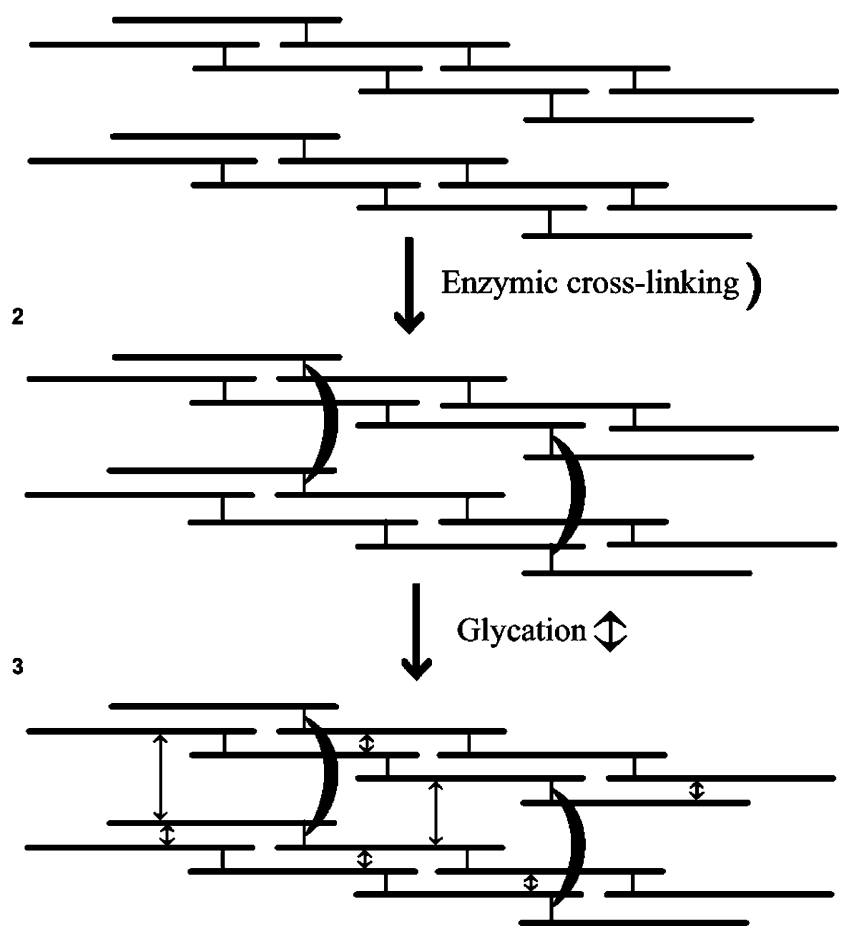

Fig. 2 Collagen maturation. As the tissue matures, immature collagen fibres with divalent cross-links ( 1 ) are enzymatically converted to mature collagen fibres with stable trivalent cross-links (2). The mature, slowly metabolising collagen is susceptible to non-enzymatic cross-linking, also known as glycation or Maillard reaction with the formation of advanced glycation endproducts (3) 
binding proteins, cell surface receptors and cell-cell adhesion molecules [26]. MMPs are being synthesised intracellularly and secreted as pro-enzymes into the extracellular space, which requires conversion to the active form for enzymatic activity. Twenty-three different members of the MMP family have been identified in humans. They all can degrade one or more extracellular matrix components, however, with different specificities. The interstitial and neutrophil collagenases (MMP-1, MMP-8, MMP-13) are capable of cleaving fibrillar collagen, while the gelatinases (MMP-2 and MMP-9) degrade the resulting denatured peptides. Acid cathepsins depolymerise collagen fibres by cleaving near cross-link sites. The combined action of these enzymes is capable of degrading all components of the extracellular matrix.

To limit connective tissue degradation, the activity of MMPs is regulated by modulation of pro-enzyme production [27]. Overdegradation is also regulated by endogenous inhibitors: serum-borne inhibitors and the tissue-derived inhibitors of metalloproteinases (TIMPs). They bind stoichiometrically to MMPs to inhibit their activity. TIMP-1, as well as TIMP-3, binds to MMP-1 and MMP-9; TIMP-2 binds to MMP-2 [28, 29]. Recently, those that have been formed in vitro have shown that active MMPs can also be inactivated spontaneously by degradation into smaller fragments. This process is referred to as autocatalysis $[30,31]$.

\section{Elastin}

The mechanical properties of tissues are also dependent on the proportion of elastin, an insoluble polymer that is formed by the assembly of tropo-elastin monomers followed by catalysis of cross-link formation by lysyl oxidases (LOX). Elastin allows the tissue to stretch and return to its original shape without energy input [32]. This property of resilience is presumed important for reproductive tissues. It accommodates the enormous expansion in pregnancy and involution after parturition. Production of elastin is unique among connective tissue proteins. In most organs, elastin biosynthesis is limited to a brief period of development. The assembly of elastic fibres is complete by maturity when tropo-elastin synthesis ceases. In undisturbed tissues, elastic fibres produced in the third trimester of foetal life last the rest of life [33]. In the female reproductive tract, however, elastic fibre turnover appears to be continuous. Recently, it is found that LOX is essential for elastic fibre homeostasis in many tissues, including the female pelvic organs. Mice lacking LOXL1 are unable to synthesise elastin polymers in adult tissue, whereas collagen synthesis appears to proceed normally. These mice also fail to replenish mature elastin fibres in the reproductive tract after parturition. They develop spontaneous prolapse [33, 34]. Fibulin-5, which is an elastic binding protein crucial for elastic fibre assembly [35], is believed to act as a bridge between cells and tropo-elastin for effective cross-linking and assembly of tropo-elastin into mature elastic fibres. Increased synthesis of tropo-elastin and fibulin-5 may be necessary to counteract for disruption of elastic fibres and to regenerate elastic fibres in the vaginal wall. In fibulin-5 knock-out mice, POP was similar to that in primates, suggesting that synthesis and assembly of elastic fibres are crucial for recovery of pelvic organ support after damage. Disordered elastic fibre homeostasis seems to be a primary event in the pathogenesis of POP in mice [36].

\section{Pelvic floor connective tissue in POP}

\section{Collagen synthesis and subtypes in POP}

Studies on changes in the quantity and ratios of subtypes of collagen produced inconclusive data. Both increase and reduction of total collagen content of vaginal and pelvic floor supportive tissues in patients with POP have been reported (Table 1). Different methods of quantification of collagen content and also the lack of information on tissue histology and biopsy site of the vagina or supportive tissue that was analysed make direct comparison between studies difficult. Table 1 shows that tissue obtained from uterine ligaments of patients with POP seems to show a decreased total collagen content [11, 37-39] with a higher concentration of collagen III [40-43] irrespective of age or parity. An increased collagen III content may suggest tissue repair after overstretching of the supportive connective tissue of the pelvic floor. Moalli et al. [41] also found a significantly increased expression of active MMP-9 in women with POP relative to controls. An increase in collagen III in combination with an increase in active MMP-9 is typical of tissue that is remodelling after injury or a tissue that is remodeling to accommodate a progressively increasing mechanical load [44]. A higher expression of tenascin, an extracellular matrix glycoprotein that reappears around healing wounds [42], supports this theory.

\section{Cross-linking of collagen in POP}

There is more to collagen than just the total amount and the subtypes. Barbiero et al. [45] performed a qualitative analysis of type I collagen in the parametrium of patients with and without POP. It was demonstrated that the parametrium consists of shorter, thinner and more disorderly arranged collagen fibres in patients with uterine prolapse compared to healthy controls.

The maturity of the tissue depends on the relative proportion of the divalent cross-links to the mature 
Table 1 Collagen analysis in biopsy specimens from vaginal or supportive tissue in women with or without POP

\begin{tabular}{|c|c|c|c|c|}
\hline Study & $\begin{array}{l}\text { Target population and } \\
\text { sample size }\end{array}$ & Tissue analysed & Analytic methods & $\begin{array}{l}\text { Findings: patients with POP } \\
\text { compared to controls }\end{array}$ \\
\hline Makinen 1987 [61] & $\begin{array}{l}5 \text { women with uterine } \\
\text { prolapse } \\
5 \text { controls }\end{array}$ & Vaginal fascia & $\begin{array}{l}\text { Collagen I mRNA in fibroblasts } \\
\text { cultured from vaginal biopsies }\end{array}$ & $\begin{array}{l}\text { No difference in collagen I } \\
\text { mRNA }\end{array}$ \\
\hline Jackson 1996 [13] & $\begin{array}{l}8 \text { premenopausal } \\
\text { women with POP } \\
10 \text { controls }\end{array}$ & Vaginal epithelium & $\begin{array}{l}\text { Hydroxyproline assay, protein } \\
\text { analysis of collagen a chains }\end{array}$ & $\begin{array}{l}\text { Decreased total collagen No } \\
\text { difference in ratio collagen I/III }\end{array}$ \\
\hline Kökçü 2001 [58] & $\begin{array}{l}24 \text { premenopausal } \\
\text { women with POP } \\
21 \text { controls }\end{array}$ & $\begin{array}{l}\text { Vaginal fascia in } \\
\text { precervical region, } \\
\text { cardinal, uterosacral } \\
\text { and round ligaments }\end{array}$ & $\begin{array}{l}\text { Histology with haematoxylin and } \\
\text { eosine, Gomori's trichome and } \\
\text { Verhoeff elastic stains followed } \\
\text { by light microscopy }\end{array}$ & Increased total collagen \\
\hline Liapis 2001 [96] & $\begin{array}{l}34 \text { women with SUI } \\
\text { and POP } \\
32 \text { women with POP } \\
28 \text { controls }\end{array}$ & $\begin{array}{l}\text { Paravaginal fascia and } \\
\text { the uterosacral } \\
\text { ligaments }\end{array}$ & $\begin{array}{l}\text { Immunohistochemical analysis } \\
\text { and light microscopy }\end{array}$ & $\begin{array}{l}\text { Decreased collagen III in SUI and } \\
\text { POP, no significant difference in } \\
\text { women with POP alone } \\
\text { compared with controls }\end{array}$ \\
\hline Takano 2002 [38] & $\begin{array}{l}10 \text { premenopausal } \\
\text { women with POP } \\
23 \text { postmenopausal } \\
\text { women with POP } \\
22 \text { controls }\end{array}$ & $\begin{array}{l}\text { Lateral parametrium } \\
\text { and vaginal apex }\end{array}$ & Histology with picrosirius & $\begin{array}{l}\text { Decreased collagen in lateral } \\
\text { parametrium in POP in women } \\
\text { with POP compared with } \\
\text { controls }\end{array}$ \\
\hline Ewies 2003 [42] & $\begin{array}{l}33 \text { women with POP } \\
25 \text { controls }\end{array}$ & Cardinal ligaments & $\begin{array}{l}\text { Histological confirmation } \\
\text { immunohistochemistry }\end{array}$ & $\begin{array}{l}\text { Increased collagen III, but } \\
\text { suppressed effect by HT }\end{array}$ \\
\hline Goepel 2003 [97] & $\begin{array}{l}15 \text { postmenopausal } \\
\text { women with POP } \\
14 \text { postmenopausal } \\
\text { women with POP and } \\
\text { SUI }\end{array}$ & Periurethral ligaments & $\begin{array}{l}\text { Immunohistochemistry and light } \\
\text { microscopy }\end{array}$ & $\begin{array}{l}\text { Decreased collagen I, III and VI } \\
\text { in women with SUI } \\
\text { Decreased total collagen in } \\
\text { women with POP }\end{array}$ \\
\hline Moalli 2004 [40] & $\begin{array}{l}10 \text { premenopausal } \\
\text { women } \\
5 \text { postmenopausal } \\
\text { women } \\
12 \text { postmenopausal } \\
\text { women with HT }\end{array}$ & ATFP & $\begin{array}{l}\text { Laser scanning confocal } \\
\text { microscopy and } \\
\text { immunofluorescence }\end{array}$ & $\begin{array}{l}\text { Decreased collagen I in } \\
\text { postmenopausal women } \\
\text { Increased collagen I in } \\
\text { postmenopausal women with HT } \\
\text { Decreased ratio collagen I/III in } \\
\text { postmenopausal women and } \\
\text { increased with HT }\end{array}$ \\
\hline Wong 2003 [39] & $\begin{array}{l}14 \text { women with POP } \\
17 \text { controls }\end{array}$ & Uterine cervix & Hydroxyproline assay & Decreased total collagen \\
\hline Soderberg 2004 [11] & $\begin{array}{l}22 \text { women with POP } \\
13 \text { women without } \\
\text { POP }\end{array}$ & Paraurethral ligaments & Hydroxyproline assay & $\begin{array}{l}\text { Decreased total collagen in } \\
\text { women with POP }<53 \text { years; no } \\
\text { difference in POP and controls } \\
>53 \text { years }\end{array}$ \\
\hline Gabriel 2005 [83] & $\begin{array}{l}25 \text { women with POP } \\
16 \text { controls }\end{array}$ & Uterosacral ligaments & Immunohistochemistry & Increased collagen III \\
\hline Moalli 2005 [41] & $\begin{array}{l}31 \text { premenopausal } \\
\text { women: } 16 \text { women } \\
\text { with POP, } 15 \text { controls } \\
46 \text { postmenopausal } \\
\text { women with POP: } 23 \\
\text { women on HT, } 23 \\
\text { women without HT }\end{array}$ & $\begin{array}{l}\text { Full thickness vaginal } \\
\text { apex }\end{array}$ & $\begin{array}{l}\text { Histology, laser scanning } \\
\text { confocal microscopy and } \\
\text { immunofluorescence, gelatin } \\
\text { zymography }\end{array}$ & $\begin{array}{l}\text { Increased total collagen in } \\
\text { premenopausal women with } \\
\text { POP and postmenopausal } \\
\text { women without HT } \\
\text { Decreased total collagen in } \\
\text { women with POP and SUI } \\
\text { Increased collagen III in women } \\
\text { with POP } \\
\text { No difference in collagen I and V } \\
\text { in women with POP }\end{array}$ \\
\hline
\end{tabular}

SUI stress urinary incontinence, $H T$ hormone therapy 
(trivalent) cross-links. Furthermore, mature, slowly metabolising collagen is susceptible to non-enzymatic glycation and some of these AGEs, such as pentosidine, are additional cross-linking compounds that may further inhibit the turnover of collagen.

Jackson [13] showed that POP was associated with a significant rise in the immature cross-link. The mature pyridinoline cross-linking was not altered. Pentosidine was increased significantly in the prolapse tissue, and pentosidine concentrations increased with increasing age in both groups, demonstrating that non-enzymatic glycation of collagen occurs slowly over a long time. This greater pentosidine concentration in prolapse tissue makes the tissue less soluble than in controls, reflecting the maturity of the tissue [46].

Only two studies describe the cross-linking of collagen fibres in POP [11, 47]. However, both studies only analysed a specific subset of cross-links, limiting their conclusions to these subsets. Söderberg et al. [11] found a decrease in extractability by pepsin digestion at young age in both women with and without POP compared to older women. This is an indicator of cross-links in the collagen molecule. It is considered a physiological effect of normal ageing. Chen et al. [47] analysed pyridinoline, the major mature collagen cross-link in fascia, in anterior vaginal wall. There was no difference between the incontinent women with
POP and the continent women without POP. This is in accordance with the findings of Jackson [13].

Collagen degradation, matrix metalloproteinase and tissue inhibitor of matrix metalloproteinase

The majority of studies on MMPs focus on synthesis (proMMP or MMP messenger RNA (mRNA)). Although the active form is the most relevant form with respect to tissue degradation, the analysis of the entire expression profile of these enzymes, including pro-enzyme, active and autocatalytic forms, should provide a more conclusive insight $[48,49]$.

Jackson [13] suggested an increased metabolic turnover of collagen, since MMP-2 and MMP-9 were significantly higher in prolapse tissue than in normal tissue. He did not assess the expression of other MMPs or the TIMPs. As shown in Table 2, an increase in pro-MMP-2 and active MMP-2 was confirmed by two other studies [43, 50]. Summarising the data of Table 2 concerning the activity of MMP point to a condition in which the degradation of connective tissue is accelerated in the vagina and the supportive tissue of patients with POP by an increased expression of pro- and/or active metalloproteinases in combination with a decrease in TIMP-1 mRNA and active TIMP-1 expression [47].

Table 2 Analysis of matrix metalloproteinases and tissue inhibitor of matrix metalloproteinase in biopsy specimens from vaginal or supportive tissue in women with or without POP

\begin{tabular}{|c|c|c|c|c|}
\hline Study & $\begin{array}{l}\text { Target population and } \\
\text { sample size }\end{array}$ & Tissue analysed & Analytic methods & $\begin{array}{l}\text { Findings: patients with POP } \\
\text { compared to controls }\end{array}$ \\
\hline Jackson 1996 [13] & $\begin{array}{l}8 \text { premenopausal women } \\
\text { with POP and } 10 \text { controls }\end{array}$ & $\begin{array}{l}\text { Vaginal } \\
\text { epithelium }\end{array}$ & Hydroxyproline assay & $\begin{array}{l}\text { Increase of pro MMP-2, active } \\
\text { MMP-2 and MMP-9 }\end{array}$ \\
\hline Chen 2002 [47] & $\begin{array}{l}7 \text { women with POP and } \\
\text { SUI and } 15 \text { controls }\end{array}$ & $\begin{array}{l}\text { Anterior vaginal } \\
\text { wall }\end{array}$ & $\begin{array}{l}\text { Quantitative competitive } \\
\text { reverse transcription PCR }\end{array}$ & $\begin{array}{l}\text { Decreased TIMP-1 mRNA and } \\
\text { increased MMP-1 mRNA } \\
\text { No difference in TIMP-2 and } \\
\text { TIMP-3 mRNA or MMP-2, } \\
\text { MMP-9 }\end{array}$ \\
\hline \multirow[t]{2}{*}{ Moalli 2005 [41] } & $\begin{array}{l}31 \text { premenopausal women: } \\
16 \text { women with POP, } 15 \\
\text { controls }\end{array}$ & \multirow[t]{2}{*}{$\begin{array}{r}\text { Full thickness } \\
\text { vaginal apex }\end{array}$} & \multirow[t]{2}{*}{$\begin{array}{l}\text { Histology, laser scanning } \\
\text { confocal microscopy and } \\
\text { immunofluorescence, gelatin } \\
\text { zymography }\end{array}$} & $\begin{array}{l}\text { Increased active MMP-9 in } \\
\text { premenopausal women with POP } \\
\text { and in postmenopausal women } \\
\text { with HT }\end{array}$ \\
\hline & $\begin{array}{l}46 \text { postmenopausal } \\
\text { women with POP: } 23 \\
\text { women on HT, } 23 \text { women } \\
\text { without HT }\end{array}$ & & & $\begin{array}{l}\text { No difference in the expression of } \\
\text { pro-MMP-2, active MMP- } 2 \text { or } \\
\text { pro-MMP } 9\end{array}$ \\
\hline Gabriel 2005 [43] & $\begin{array}{l}17 \text { women with POP } \\
18 \text { controls }\end{array}$ & $\begin{array}{c}\text { Uterosacral } \\
\text { ligaments }\end{array}$ & Immunohistochemistry & $\begin{array}{l}\text { Increased expression of MMP- } 2 \\
\text { No difference in expression of } \\
\text { MMP-1 }\end{array}$ \\
\hline Philips 2006 [50] & $\begin{array}{l}14 \text { women with POP } \\
14 \text { controls }\end{array}$ & $\begin{array}{l}\text { Uterosacral } \\
\text { ligaments and } \\
\text { vaginal } \\
\text { epithelial tissue }\end{array}$ & Immunohistochemistry & $\begin{array}{l}\text { In vaginal epithelium: increased } \\
\text { expression of pro-MMP-2 } \\
\text { No difference in active MMP-2, } \\
\text { MMP-9 and TIMP-2 }\end{array}$ \\
\hline
\end{tabular}

E2 estradiol, SUI stress urinary incontinence, $H T$ hormone therapy 


\section{Elastin metabolism in POP}

The importance of elastic fibres in maintaining vaginal support is demonstrated by genetic connective tissue diseases like Marfan's syndrome (mutations in fibrillingene) and cutis laxa (mutation in elastin and fibulin-5 genes). An increased incidence of POP is seen in women affected by these connective tissue diseases [51, 52].

Some changes in elastin expression in relation to POP are reported (Table 3). But the ways by which elastin is measured also vary: via mRNA level, precursor protein levels or mature elastin levels. Elastin mRNA is a few steps away from the actual elastin. Also, the protein precursor of elastin, tropo-elastin, can be measured without actually measuring the amount of mature elastin [48, 53]. A common way to quantify mature elastin used by Jackson is by indirectly measuring its cross-links with desmosine [54]. This measurement could be inaccurate, however, when studying a disease such as POP in which the crosslinking process may be disrupted and desmosine concentration is more reflective of diminished cross-linking than the total amount of elastin [48]. The most direct and thus appropriate way to measure elastin is by immunohistochemistry [53].
Even though the techniques used to obtain the data vary and thus provide inconclusive data, there is circumstantial evidence that a deficient synthesis and degradation of elastic fibres may be associated with POP [42, 53, 55-57].

The fibroblast in POP

If the collagen content in POP is changed, this may be caused by differences in the number of fibroblasts (cellularity) in the connective tissue $[58,59]$. But, the quality, i.e. functionality of the fibroblast, may also be important in the pathogenesis of POP. There is some indication that the contractibility of the vaginal (myo)fibroblasts is decreased in POP patients, which may result in deficient collagen [60]. In models of wound healing, skin myofibroblasts control the contractile and strength of the tissue, which is regulated by the so-called endothelin-1 (ET-1) system. Poncet et al. [60] compared cultures of $\alpha$-smooth muscle actin-positive myofibroblasts that were established from POP patients to myofibroblasts from primiparous women with respect to their expression of the ET-1 system and contractile properties. They found that spontaneous contraction of myofibroblasts from estrogen-treated women with POP was significantly lower than from young primiparous

Table 3 Analysis of elastin in biopsy specimens from vaginal or supportive tissue in women with or without POP

\begin{tabular}{|c|c|c|c|c|}
\hline Study & $\begin{array}{l}\text { Target population and } \\
\text { sample size }\end{array}$ & Tissue analysed & Analytic methods & $\begin{array}{l}\text { Findings: patients with POP } \\
\text { compared to controls }\end{array}$ \\
\hline Yamamoto 1997 [57] & $\begin{array}{l}4 \text { postmenopausal } \\
\text { women with POP } \\
4 \text { controls }\end{array}$ & $\begin{array}{l}\text { Cultured fibroblasts } \\
\text { from cardinal } \\
\text { ligaments }\end{array}$ & $\begin{array}{l}\text { mRNA by Northern blot analysis } \\
\text { Tropo-elastin by Western blot } \\
\text { analysis }\end{array}$ & $\begin{array}{l}\text { Decreased mRNA and tropo- } \\
\text { elastin production by fibroblast }\end{array}$ \\
\hline Ewies 2003 [42] & $\begin{array}{l}33 \text { women with POP } \\
25 \text { controls }\end{array}$ & Cardinal ligaments & $\begin{array}{l}\text { Histological confirmation } \\
\text { immunohistochemistry }\end{array}$ & Decreased elastin content \\
\hline Chen 2004 [55] & $\begin{array}{l}12 \text { women with SUI and } \\
\text { or POP } 15 \text { controls }\end{array}$ & Periurethral vaginal wall & $\begin{array}{l}\text { Quantitative competitive-PCR } \\
\text { mRNA and confirmatory } \\
\text { Western blot analyses }\end{array}$ & $\begin{array}{l}\text { Decrease in endogenous inhibitors } \\
\text { of elastases with increase in } \\
\text { elastolytic activity resulting in } \\
\text { decrease in elastin content }\end{array}$ \\
\hline Goepel 2007 [56] & $\begin{array}{l}29 \text { postmenopausal with } \\
\text { POP } \\
30 \text { controls }\end{array}$ & Uterosacral ligaments & $\begin{array}{l}\text { Immunofluorescence microscopy } \\
\text { elastin/tenascin }\end{array}$ & $\begin{array}{l}\text { Decreased elastin content, } \\
\text { increased tenascin content }\end{array}$ \\
\hline Karam 2007 [53] & $\begin{array}{l}33 \text { women with POP } \\
10 \text { controls }\end{array}$ & Anterior vaginal wall & $\begin{array}{l}\text { Histological confirmation } \\
\text { immunohistochemistry }\end{array}$ & Decreased elastin content \\
\hline Klütke 2008 [98] & $\begin{array}{l}31 \text { women with POP } \\
29 \text { controls }\end{array}$ & Uterosacral ligaments & $\begin{array}{l}\text { Desmosine by } \\
\text { radioimmunoassay; quantitative } \\
\text { real-time PCR mRNA levels of } \\
\text { LOX, LOXL1, LOXL2 and } \\
\text { (FIB-5) }\end{array}$ & $\begin{array}{l}\text { Decreased desmosine content } \\
\text { Suppression of mRNA for LOX } \\
\text { and two LOX isoenzymes }\end{array}$ \\
\hline Lin 2006 [99] & $\begin{array}{l}23 \text { women with POP } \\
15 \text { controls }\end{array}$ & Anterior vaginal wall & Immunohistochemistry & No difference \\
\hline Jackson 1996 [13] & $\begin{array}{l}8 \text { premenopausal } \\
\text { women with POP } \\
10 \text { controls }\end{array}$ & Vaginal epithelium & $\begin{array}{l}\text { Desmosine by modified ion- } \\
\text { exchange method }\end{array}$ & No difference \\
\hline
\end{tabular}

LOX lysyl oxidase, LOXL1 lysyl oxidase like-1; FIB-5 fibulin-5, SUI stress urinary incontinence 
women. Addition of exogenous endothelin-1 decreased the spontaneous contraction of myofibroblasts, which is opposite to observations in skin myofibroblasts.

Makinen et al. [61] studied the rates of collagen synthesis and procollagen mRNA levels in cultured fascia fibroblasts of patients with POP. They found that these fibroblasts exhibited rates of collagen synthesis similar to or slightly higher than those from age-matched controls. This finding suggests that POP is not related to defects in the capacity of vaginal fibroblasts to synthesise or process procollagen. The existence of a possible qualitative change in type I and or type III collagen could not be ruled out in this study. There are no indications of mutations in the various polypeptides in collagen type I and III. Mutations could produce minor changes in collagen fibres that would make connective tissue less able to withstand the stresses of an individual lifespan and could explain predisposition to common diseases affecting connective tissue.

With respect to the production of elastin, the elastin gene expression and protein synthesis in fibroblasts derived from cardinal ligaments of patients with POP is markedly lower than in non-POP patients [57]. This may be a result of a decreased expression of the wild-type p53 mRNA and wildtype p53 protein in fibroblasts of women with POP. Cells fail to enter quiescence ( $\mathrm{G} 0$ phase) that may lead to a decrease in synthesis and deposition of elastin.

The synthesis of components of the ECM by fibroblasts is influenced by stretch. Whether it is cause or effect, prolapsed tissue is stretched tissue. Ewies demonstrated recently that mechanical stretch disturbs the fibroblasts' ability to maintain the cytoskeleton architecture. The use of estrogens did not reverse the process or protect the cells from the effect of stretch, but significantly increased the rate of fibroblast proliferation, suggesting their role in the healing process [62].

These results suggests, in contrast to the findings of collagen production, that functional changes in the fibroblasts of the cardinal ligaments are involved in the mechanism of prolapse development $[57,63,64]$. In relation to POP in which tissue is stretched, it is demonstrated that mechanical stretch disturbs the fibroblasts' ability to maintain their cytoskeleton architecture and we speculate that they may disrupt ligamentous integrity and result in clinical prolapse.

The role of estrogen in collagen metabolism in POP

As estrogen deficiency is a known risk factor for POP [65], estrogen replacement therapy traditionally has been used to improve structural integrity of the pelvic tissue with favourable effects on urinary incontinence[66-69]. Previously, estrogen receptors (ER) were identified in the nuclei of connective tissue and of the smooth muscle cells of the bladder trigone, urethra, vaginal mucosa, levator ani stromal and uterosacral ligament. Two different subtypes have been found in human cells: ER- $\alpha$ is the dominant receptor in the adult uterus, whereas ER- $\beta$ is expressed at high levels in other estrogen-target tissues such as prostate, testis, ovary, smooth muscle, vascular endothelium and immune system. These receptors participate in maintaining the supportive system of the pelvic by a.o. increasing synthesis or by decreasing breakdown of collagen and other extracellular matrix proteins [70]. Few studies have been done to assess the tissue expression levels of sex steroid hormone receptors in patients with POP. Lower estrogen receptor expression in patients with POP have been found in combination with lower serum concentrations of estrogen $[65,71]$. In contrast, higher sex steroid hormone receptor expression in POP patients has also been described [72].

Several studies report an increase in the mRNA expression for collagen I and III in estrogen replacement therapy $[30,73,74]$. These findings suggest that estrogen increases the turnover of connective tissues of the pelvic floor. It is also suggested that estrogen restores the collagen metabolism to a premenopausal state [41]. In a doubleblind, placebo-controlled trial with postmenopausal women with urinary stress incontinence treated with estradiol therapy, Jackson [13] found strong evidence for both new synthesis and degradation. The immature cross-links were increased, indicating newly synthesised collagen. However, the ratio of type I/III collagen was unchanged in the estradiol treated group, and the total collagen content was significantly decreased. Also, an elevation of both the proactive and active forms of MMP-2 and MMP-9 in women treated with estradiol compared to controls was found. This resulted in a decrease in total collagen content [75]. Also, a combination of upregulation of MMPs and suppression of TIMP by estrogen resulted in an increase of ECM breakdown [76].

Inhibition of MMP by estrogen therapy is also reported [77, 78]. Zong et al. [49] found that only E2 combined with progesterone decreased the active form of MMP-1, which suggests that both hormones are necessary to maintain the integrity of the female pelvic floor.

With respect to elastin, Moalli et al. [40] found no differences between pre-, post- and postmenopausal women on hormone therapy.

\section{Estrogens and fibroblasts}

$17 \beta$-Estradiol may have a suppressive effect on proliferation of fibroblasts, derived from cardinal ligaments in patients with POP. Therefore, $17 \beta$-estradiol may have a role in inducing POP by negatively affecting the concentration of fibroblasts in pelvic organ connective tissue [79].

Estrogen therapy, thus, induces turnover of collagen, but the precise role of estrogen in collagen metabolism related 
to POP is still unclear. Data suggest an increased mRNA expression of collagen type I and III as a reaction to hormone replacement therapy, with a concomitant increased synthesis of these collagen types. However, an increased activity of MMP, resulting in an increase in collagen degradation, is also reported. Whether sex steroid receptors are a primary cause or a downstream effect of POP remains unknown.

\section{Discussion}

The development of POP is multifactorial. Factors contributing to the development of POP can be divided into genetic and acquired factors [1]. Genetics and race predispose a certain population of women to POP. Inciting factors include pregnancy and parity as well as myopathy and neuropathy. Obesity, smoking, pulmonary disease and obstipation are examples of POP-promoting factors. Patients with these risk factors tend to develop POP in a higher frequency with ageing and menopause as superimposing decompensation factors.

Several studies have underlined the role of a strength deficit of urogenital tissues, which is attributed to changes in synthesis and degradation of different types of collagen and elastin in POP development [80]. Also, the function of supporting and contractile cells, the fibroblasts, may be disturbed [60]. However, data on the changes in collagen metabolism in patients with POP are conflicting. The differences may partly be due to the analysis of different target tissue in patients with POP. The tissue which supports the vagina and the pelvic organs can be divided into the suspensory system part (Delanceys' level I and II) and the supportive part (level III) [14, 81]. The quantity, type and organisation of collagen, elastin and smooth muscles cells vary within the different tissues [41]. Tissues from all three levels were used to study the possible defects in collagen metabolism in patients with POP without defining and relating them to the type and stage of the prolapse. Beside the variety in biopsy sites, the majority of the studies do not define tissue histology, making it difficult to determine exactly which portion (e.g. epithelium vs. subepithelium) is being analysed. Histology of the paracolpium and uterosacral and cardinal ligaments demonstrates that these structures have a different composition when compared to the vaginal tissue. Also, variation in biochemical tests that are used for the analysis of vaginal/ pelvic tissues in women with POP and the heterogeneity in the populations studied contribute to the inconsistency of the results in the literature on connective tissue components of vaginal/pelvic tissue in relation to POP [53].

Noteworthy is the way in which collagen and elastin are measured: through mRNA, precursor protein or mature levels of collagen or elastin. Measuring mRNA that still needs to be translated and will undergo further posttranslational modification and turnover will not reflect the resulting levels of mature elastin protein. Also, the amount of precursor protein may not reflect the actual amount of mature collagen or elastin $[48,53]$. With respect to studies on MMP, the focus should not only be on pro-MMP or MMP mRNA but on the entire expression profile $[48,49]$.

\section{Summery and perspective}

In 1996, Jackson formulated his theory about the pathogenesis of POP [13]. He postulated that in young patients with POP, a higher turnover of immature collagen [11] resulted in a bulk of deficient glycated old collagen that is difficult to degrade. This glycated collagen, which is brittle and susceptible to rupture, may result in POP. Despite numerous shortcomings in the available literature, the hypothesis of Jackson [13] still appears to be valid [11, $38-41,47,49,50,82,83]$.

In prolapsed tissue, the fibroblasts exhibit more collagen production, an increased MMP-2 and MMP-9 activity and a decrease of the activity of TIMP-1, resulting in an increased turnover of collagen. In particular, the breakdown of immature newly formed collagen is increased. The total collagen content is generally lower in POP patients compared with non-POP patients. The content of AGEs is increased in patients with $\mathrm{POP}$, which makes them susceptible for developing POP over time.

Jackson [13] found no change in the type I to type III ratio. Most studies, however, found an increase in type III $[41,42,58,83]$ and/or a decrease in type I $[11,38,40]$, thus resulting in a decreased I/III ratio. An increase in the expression of both collagen type III and MMP-9 expression is typical of tissue that is remodelling after injury [84] or accommodating to a progressively increasing mechanical load $[44,85]$. In particular, an increase in MMP-9 specifically in women with POP found by Jackson and confirmed by Moalli [41] has been associated with tissue remodelling in bone [86], coronary artery [87] and healing dermal wounds [88].

Parity is the strongest factor in the development of POP, with an adjusted relative risk of 10.85 (95\% CI 4.65-33.81) [5]. During childbirth, neuromuscular damage occurs. It is not only direct injury to the levator ani muscle resulting in mechanical disruption of the entire muscle but also damage to the nerve supply of the muscle that could lead to their inability to contract, even though the muscles remain intact $[89,90]$. When the pelvic floor muscles relax or are damaged, the genital hiatus opens and the pelvic organs must be held in place by the suspensory ligaments. Although the ligaments can sustain these loads for short periods of time, the connective tissues will stretch and eventually fail if 
the pelvic floor muscles do not close the pelvic floor in time. Physiological aging and menopause are decompensating factors in this process [91]. It is therefore likely that after an injury such as childbirth, the supporting connective tissue of the vaginal wall will remodel in order to adapt to the tensile stress. It is hard, if not impossible, to determine whether the changes seen in collagen metabolism in women with POP do reflect the cause or the effect of prolapse. Alternatively, it may well be that POP is related to abnormal repair of the injured tissue after the stress of delivery [92]. In either case, the increased flexibility, dispensability and decreased tensile strength associated with an increase in collagen III, together with a decrease in elastin levels, will very likely contribute to the progression of POP. Whether the change in biomechanical properties is also caused by a change in the concentration of intermolecular cross-linking analysed in only two studies [11,47], which both support the findings of Jackson, may need further studies in order to be able to substantiate this conclusion.

In future studies, a better comparison requires standardisation of biopsy sites with histological confirmation. Also, standardisation of complementary and confirmatory methods of protein quantification is obligatory.

More knowledge is needed about the roles of the different types of collagen, collagen turnover and breakdown, as well as the interaction between collagen maintenance, elastin metabolism, genetic components and parity in the pathophysiology of POP. Also, information about the intrinsic quality of the collagens, collagen cross-linking and the mechanisms by which collagen production and breakdown are out of balance in POP patients is, in general, still lacking. It may be postulated that most conclusive answers will be obtained from young POP patients, in which the genetic component may be expected to be more pronounced compared to older POP patients.

The focus of research should also be on the mechanism of fibroblasts reacting on mechanical loading, typing of the collagens produced by fibroblasts and MMP production by fibroblasts in POP and non-POP patients. This is of particular interest when patients' own stem cells are used as a therapeutic means to restore the collagen homeostasis. Stem cells have been used to create striated sphincter muscle in vitro [93]. Also, autologous myoblasts and fibroblasts were injected lateral from the urethra to treat urinary incontinence [94-95]. Ideally, it should be possible to develop a biocompatible and bioresorbable scaffold with appropriate mechanical properties in which stem cells are able to contribute to tissue regeneration by proliferation and differentiation into (myo)fibroblasts and by formation of the appropriate connective tissue. If, however, autologous fibroblasts of POP patients are unable to produce a good quality extracellular matrix due to their genetic background, the use of allogenic stem cells could be considered.

\section{Conclusion}

Recent literature data support the hypothesis of Jackson formulated in 1996-more brittle collagen in pelvic floor connective tissue that is difficult to degrade in POP patients compared to non-POP patients- but do not resolve longstanding questions on the aetiology of POP.

Acknowledgements We would like to thank Prof Dr R. Bank (matrix biologist; TNO Quality of Life) and M.N. Helder, Ph.D. biochemist, for reading the manuscript and I. Riphagen, clinical librarian, for her assistance with the literature search.

Conflicts of interest None.

Open Access This article is distributed under the terms of the Creative Commons Attribution Noncommercial License which permits any noncommercial use, distribution, and reproduction in any medium, provided the original author(s) and source are credited.

\section{References}

1. Bump RC, Norton PA (1998) Epidemiology and natural history of pelvic floor dysfunction. Obstet Gynecol Clin North Am 25:723-746

2. Dietz HP, Haylen BT, Vancaillie TG (2002) Female pelvic organ prolapse and voiding function. Int Urogynecol $\mathrm{J}$ Pelvic Floor Dysfunct 13:284-288

3. Olsen AL, Smith VJ, Bergstrom JO, Colling JC, Clark AL (1997) Epidemiology of surgically managed pelvic organ prolapse and urinary incontinence. Obstet Gynecol 89:501-506

4. Bai SW, Choe BH, Kim JY, Park KH (2002) Pelvic organ prolapse and connective tissue abnormalities in Korean women. $\mathrm{J}$ Reprod Med 47:231-234

5. Mant J, Painter R, Vessey M (1997) Epidemiology of genital prolapse: observations from the Oxford Family Planning Association Study. Br J Obstet Gynaecol 104:579-585

6. Buchsbaum GM, Duecy EE, Kerr LA, Huang LS, Perevich M, Guzick DS (2006) Pelvic organ prolapse in nulliparous women and their parous sisters. Obstet Gynecol 108:1388-1393

7. Nikolova G, Lee H, Berkovitz S, Nelson S, Sinsheimer J, Vilain E et al (2007) Sequence variant in the laminin gamma 1 (LAMC1) gene associated with familial pelvic organ prolapse. Human Genetics 120:847-856

8. Twiss C, Triaca V, Rodriguez LV (2007) Familial transmission of urogenital prolapse and incontinence. Curr Opin Obstet Gynecol 19:464-468

9. Chiaffarino F, Chatenoud L, Dindelli M, Meschia M, Buonaguidi A, Amicarelli F et al (1999) Reproductive factors, family history, occupation and risk of urogenital prolapse. Eur J Obstet Gynecol Reprod Biol 82:63-67

10. Norton PA, Baker JE, Sharp HC, Warenski JC (1995) Genitourinary prolapse and joint hypermobility in women. Obstet Gynecol 85:225-28

11. Soderberg MW, Falconer C, Bystrom B, Malmstrom A, Ekman G (2004) Young women with genital prolapse have a low collagen concentration. Acta Obstet Gynecol Scand 83:1193-1198

12. Bhatia NN, Ho MH (2004) Stem cell therapy for urinary incontinence and pelvic floor disorders: a novel approach. Curr Opin Obstet Gynecol 16:397-398

13. Jackson SR, Avery NC, Tarlton JF, Eckford SD, Abrams P, Bailey AJ (1996) Changes in metabolism of collagen in genitourinary prolapse. Lancet 347:1658-1661 
14. Delancey JO (1992) Anatomic aspects of vaginal eversion after hysterectomy. Am J Obstet Gynecol 166:1717-1724

15. Reay Jones NH, Healy JC, King LJ, Saini S, Shousha S, lenMersh TG (2003) Pelvic connective tissue resilience decreases with vaginal delivery, menopause and uterine prolapse. Br J Surg 90:466-472

16. Goh JT (2003) Biomechanical and biochemical assessments for pelvic organ prolapse. Curr Opin Obstet Gynecol 15:391-394

17. Ramachandran G, Kartha G (1955) Structure of collagen. Nature 176:593-395

18. Bailey AJ (2001) Molecular mechanisms of ageing in connective tissues. Mech Ageing Dev 122:735-755

19. Haukipuro K (1991) Synthesis of collagen types I and III in reincised wounds in humans. Br J Surg 78:708-712

20. Hibbs MS, Postlethwaite AE, Mainardi CL, Seyer JM, Kang AH (1983) Alterations in collagen production in mixed mononuclear leukocyte-fibroblast cultures. J Exp Med 157:47-59

21. Birk DE (2001) Type V collagen: heterotypic type I/V collagen interactions in the regulation of fibril assembly. Micron 32:223237

22. Birk DE, Fitch JM, Babiarz JP, Doane KJ, Linsenmayer TF (1990) Collagen fibrillogenesis in vitro: interaction of types I and V collagen regulates fibril diameter. J Cell Sci 95:649-657

23. Swift S, Woodman P, O'Boyle A, Kahn M, Valley M, Bland D et al (2005) Pelvic Organ Support Study (POSST): the distribution, clinical definition, and epidemiologic condition of pelvic organ support defects. Am J Obstet Gynecol 192:795-806

24. Bailey AJ, Paul RG, Knott L (1998) Mechanisms of maturation and ageing of collagen. Mech Ageing Dev 106:1-56

25. Paul RG, Bailey AJ (1996) Glycation of collagen: the basis of its central role in the late complications of ageing and diabetes. Int $\mathbf{J}$ Biochem Cell Biol 28:1297-1310

26. Mott JD, Werb Z (2004) Regulation of matrix biology by matrix metalloproteinases. Curr Opin Cell Biol 16:558-564

27. Curry TE Jr, Osteen KG (2003) The matrix metalloproteinase system: changes, regulation, and impact throughout the ovarian and uterine reproductive cycle. Endocr Rev 24:428-465

28. Chen B, Wen Y, Wang H, Polan ML (2003) Differences in estrogen modulation of tissue inhibitor of matrix metalloproteinase1 and matrix metalloproteinase- 1 expression in cultured fibroblasts from continent and incontinent women. Am J Obstet Gynecol 189:59-65

29. Gomez DE, Alonso DF, Yoshiji H, Thorgeirsson UP (1997) Tissue inhibitors of metalloproteinases: structure, regulation and biological functions. Eur J Cell Biol 74:111-22

30. Clark AL, Slayden OD, Hettrich K, Brenner RM (2005) Estrogen increases collagen I and III mRNA expression in the pelvic support tissues of the rhesus macaque. Am J Obstet Gynecol 192:1523-1529

31. Kremer EA, Chen Y, Suzuki K, Nagase H, Gorski JP (1998) Hydroxyapatite induces autolytic degradation and inactivation of matrix metalloproteinase-1 and -3. J Bone Miner Res 13:18901902

32. Ritz-Timme S, Laumeier I, Collins MJ (2003) Aspartic acid racemization: evidence for marked longevity of elastin in human skin. Br J Dermatol 149:951-959

33. Liu X, Zhao Y, Pawlyk B, Damaser M, Li T (2006) Failure of elastic fiber homeostasis leads to pelvic floor disorders. Am J Pathol 168:519-528

34. Alperin M, Debes K, Abramowitch S, Meyn L, Moalli PA (2008) LOXL1 deficiency negatively impacts the biomechanical properties of the mouse vagina and supportive tissues. Int Urogynecol J Pelvic Floor Dysfunct 19:977-986

35. Nakamura $T$, Lozano PR, Ikeda $Y$, Iwanaga $Y$, Hinek A, Minamisawa $S$ et al (2002) Fibulin-5/DANCE is essential for elastogenesis in vivo. Nature 415:171-175
36. Drewes PG, Yanagisawa H, Starcher B, Hornstra I, Csiszar K, Marinis SI et al (2007) Pelvic organ prolapse in fibulin-5 knockout mice: pregnancy-induced changes in elastic fiber homeostasis in mouse vagina. Am J Pathol 170:578-589

37. Buchanan S, Robertson GW, Hocking PM (2000) Effects of food restriction or delayed photostimulation on ovarian follicle number, plasma oestradiol concentration and vaginal collagen content in male-line turkeys. Br Poult Sci 41:502-507

38. Takano CC, Girao MJ, Sartori MG, Castro RA, Arruda RM, Simoes MJ et al (2002) Analysis of collagen in parametrium and vaginal apex of women with and without uterine prolapse. Int Urogynecol J Pelvic Floor Dysfunct 13:342-345

39. Wong MY, Harmanli OH, Agar M, Dandolu V, Grody MH (2003) Collagen content of nonsupport tissue in pelvic organ prolapse and stress urinary incontinence. Am J Obstet Gynecol 189:15971599

40. Moalli PA, Talarico LC, Sung VW, Klingensmith WL, Shand SH, Meyn LA et al (2004) Impact of menopause on collagen subtypes in the arcus tendineous fasciae pelvis. Am J Obstet Gynecol 190:620-627

41. Moalli PA, Shand SH, Zyczynski HM, Gordy SC, Meyn LA (2005) Remodeling of vaginal connective tissue in patients with prolapse. Obstet Gynecol 106:953-963

42. Ewies AA, Al-Azzawi F, Thompson J (2003) Changes in extracellular matrix proteins in the cardinal ligaments of postmenopausal women with or without prolapse: a computerized immunohistomorphometric analysis. Hum Reprod 18:2189-2195

43. Gabriel B, Watermann D, Hancke K, Gitsch G, Werner M, Tempfer $C$ et al (2006) Increased expression of matrix metalloproteinase 2 in uterosacral ligaments is associated with pelvic organ prolapse. Int Urogynecol J Pelvic Floor Dysfunct 17:478482

44. Chiquet M (1999) Regulation of extracellular matrix gene expression by mechanical stress. Matrix Biol 18:417-426

45. Barbiero EC, Sartori MG, Girao MJ, Baracat EC, Lima de GR (2003) Analysis of type I collagen in the parametrium of women with and without uterine prolapse, according to hormonal status. Int Urogynecol J Pelvic Floor Dysfunct 14:331-334

46. Yamauchi M, Woodley DT, Mechanic GL (1988) Aging and cross-linking of skin collagen. Biochem Biophys Res Commun 152:898-903

47. Chen BH, Wen Y, Li H, Polan ML (2002) Collagen metabolism and turnover in women with stress urinary incontinence and pelvic prolapse. Int Urogynecol J Pelvic Floor Dysfunct 13:80-87

48. Alperin M, Moalli PA (2006) Remodeling of vaginal connective tissue in patients with prolapse. Curr Opin Obstet Gynecol 18:544-550

49. Zong W, Zyczynski HM, Meyn LA, Gordy SC, Moalli PA (2007) Regulation of MMP-1 by sex steroid hormones in fibroblasts derived from the female pelvic floor. Am J Obstet Gynecol 196:349-311

50. Phillips CH, Anthony F, Benyon C, Monga AK (2006) Collagen metabolism in the uterosacral ligaments and vaginal skin of women with uterine prolapse. Br J Obstet Gynaec 113:39-46

51. Judge DP, Dietz HC (2005) Marfan's syndrome. Lancet 366:1965-1976

52. Carley ME, Schaffer J (2000) Urinary incontinence and pelvic organ prolapse in women with Marfan or Ehlers Danlos syndrome. Am J Obstet Gynecol 182:1021-1023

53. Karam JA, Vazquez DV, Lin VK, Zimmern PE (2007) Elastin expression and elastic fibre width in the anterior vaginal wall of postmenopausal women with and without prolapse. BJU Int 100:346-350

54. Starcher BC (1977) Determination of the elastin content of tissues by measuring desmosine and isodesmosine. Anal Biochem 79:1115 
55. Chen B, Wen Y, Polan ML (2004) Elastolytic activity in women with stress urinary incontinence and pelvic organ prolapse. Neurourol Urodyn 23:119-126

56. Goepel C (2007) Differential elastin and tenascin immunolabeling in the uterosacral ligaments in postmenopausal women with and without pelvic organ prolapse. Acta Histochem 110:204-209

57. Yamamoto K, Yamamoto M, Akazawa K, Tajima S, Wakimoto H, Aoyagi M (1997) Decrease in elastin gene expression and protein synthesis in fibroblasts derived from cardinal ligaments of patients with prolapsus uteri. Cell Biol Int 21:605-611

58. Kokcu A, Yanik F, Cetinkaya M, Alper T, Kandemir B, Malatyalioglu E (2002) Histopathological evaluation of the connective tissue of the vaginal fascia and the uterine ligaments in women with and without pelvic relaxation. Arch Gynecol Obstet 266:75-78

59. Makinen J, Soderstrom KO, Kiilholma P, Hirvonen T (1986) Histological changes in the vaginal connective tissue of patients with and without uterine prolapse. Arch Gynecol 239:17-20

60. Poncet S, Meyer S, Richard C, Aubert JD, Juillerat-Jeanneret L (2005) The expression and function of the endothelin system in contractile properties of vaginal myofibroblasts of women with uterovaginal prolapse. Am J Obstet Gynecol 192:426-432

61. Makinen J, Kahari VM, Soderstrom KO, Vuorio E, Hirvonen T (1987) Collagen synthesis in the vaginal connective tissue of patients with and without uterine prolapse. Eur J Obstet Gynecol Reprod Biol 24:319-325

62. Ewies AA, El-Shafie M, Li J, Stanley A, Thompson J, Styles JA et al (2008) Changes in transcription profile and cytoskeleton morphology in pelvic ligament fibroblasts in response to stretchthe effects of oestradiol and levormeloxifene. Mol Hum Reprod 14:127-135

63. Yamamoto M, Aoyagi M, Akazawa K, Tajima S, Yamamoto K (1998) Decrease in p53 protein in cultured cardinal ligament fibroblasts from patients with prolapsus uteri. Cell Biol Int 22:3140

64. Yamamoto M, Akazawa K, Aoyagi M, Yamamoto K (2000) Changes in biological characteristics during the cellular aging of ligament fibroblasts derived from patients with prolapsus uteri. Mech Ageing Dev 115:175-187

65. Bai SW, Chung DJ, Yoon JM, Shin JS, Kim SK, Park KH (2005) Roles of estrogen receptor, progesterone receptor, p53 and p21 in pathogenesis of pelvic organ prolapse. Int Urogynecol J 16:492496

66. Moehrer B, Hextall A, Jackson S (2003) Oestrogens for urinary incontinence in women. Cochrane Database Syst Rev CD001405

67. Savvas M, Bishop J, Laurent G, Watson N, Studd J (1993) Type III collagen content in the skin of postmenopausal women receiving oestradiol and testosterone implants. $\mathrm{Br} \mathrm{J}$ Obstet Gynaecol 100:154-156

68. Brincat M, Moniz CF, Kabalan S, Versi E, O'Dowd T, Magos AL et al (1987) Decline in skin collagen content and metacarpal index after the menopause and its prevention with sex hormone replacement. Br J Obstet Gynaecol 94:126-129

69. Brincat M, Kabalan S, Studd JW, Moniz CF, de Trafford J, Montgomery J (1987) A study of the decrease of skin collagen content, skin thickness, and bone mass in the postmenopausal woman. Obstet Gynecol 70:840-845

70. Da Chung J, Bai SW (2006) Roles of sex steroid receptors and cell cycle regulation in pathogenesis of pelvic organ prolapse. Curr Opin Obstet Gynecol 18:551-554

71. Lang JH, Zhu L, Sun ZJ, Chen J (2003) Estrogen levels and estrogen receptors in patients with stress urinary incontinence and pelvic organ prolapse. Int J Gynaecol Obstet 80:35-39

72. Ewies AA, Thompson J, Al Azzawi F (2004) Changes in gonadal steroid receptors in the cardinal ligaments of prolapsed uteri: immunohistomorphometric data. Hum Reprod 19:1622-1628
73. Falconer C, Ekman-Ordeberg G, Ulmsten U, WestergrenThorsson G, Barchan K, Malmstrom A (1996) Changes in paraurethral connective tissue at menopause are counteracted by estrogen. Maturitas 24:197-204

74. Rizk DE, Hassan HA, Al Marzouqi AH, Ramadan GA, Al Kedrah SS, Daoud SA et al (2008) Combined estrogen and ghrelin administration restores number of blood vessels and collagen type I/III ratio in the urethral and anal canal submucosa of old ovariectomized rats. Int Urogynecol J Pelvic Floor Dysfunct 19:547-552

75. Jackson S, James M, Abrams P (2002) The effect of oestradiol on vaginal collagen metabolism in postmenopausal women with genuine stress incontinence. Br J Obstet Gynaecol 109:339344

76. Helvering LM, Adrian MD, Geiser AG, Estrem ST, Wei T, Huang $S$ et al (2005) Differential effects of estrogen and raloxifene on messenger RNA and matrix metalloproteinase 2 activity in the rat uterus. Biol Reprod 72:830-841

77. Brincat M, Versi E, Moniz CF, Magos A, de Trafford J, Studd JW (1987) Skin collagen changes in postmenopausal women receiving different regimens of estrogen therapy. Obstet Gynecol 70:123-127

78. Moalli PA, Klingensmith WL, Meyn LA, Zyczynski HM (2002) Regulation of matrix metalloproteinase expression by estrogen in fibroblasts that are derived from the pelvic floor. Am J Obstet Gynecol 187:72-79

79. Liu YM, Choy KW, Lui WT, Pang MW, Wong YF, Yip SK (2006) 17beta-estradiol suppresses proliferation of fibroblasts derived from cardinal ligaments in patients with or without pelvic organ prolapse. Hum Reprod 21:303-308

80. Chen B, Wen Y, Zhang ZM, Wang HB, Warrington JA, Polan ML (2003) Menstrual phase-dependent gene expression differences in periurethral vaginal tissue from women with stress incontinence. Am J Obstet Gynecol 189:89-97

81. Delancey JO (1994) The anatomy of the pelvic floor. Curr Opin Obstet Gynecol 6:313-316

82. Buchanan S, Robertson GW, Hocking PM (1999) The relationships between vaginal collagen, plasma oestradiol and uterine prolapse in turkeys. Research in Veterinary Science 67:153157

83. Gabriel B, Denschlag D, Gobel H, Fittkow C, Werner M, Gitsch $G$ et al (2005) Uterosacral ligament in postmenopausal women with or without pelvic organ prolapse. Int Urogynecol J Pelvic Floor Dysfunct 16:475-479

84. Soo C, Shaw WW, Zhang X, Longaker MT, Howard EW, Ting K (2000) Differential expression of matrix metalloproteinases and their tissue-derived inhibitors in cutaneous wound repair. Plast Reconstr Surg 105:638-647

85. Sarasa-Renedo A, Chiquet M (2005) Mechanical signals regulating extracellular matrix gene expression in fibroblasts. Scand J Med Sci Sports 15:223-230

86. Ortega N, Behonick D, Stickens D, Werb Z (2003) How proteases regulate bone morphogenesis. Ann N Y Acad Sci 995:109116

87. Cai WJ, Koltai S, Kocsis E, Scholz D, Kostin S, Luo X et al (2003) Remodeling of the adventitia during coronary arteriogenesis. Am J Physiol Heart Circ Physiol 284:H31-H40

88. Gillard JA, Reed MW, Buttle D, Cross SS, Brown NJ (2004) Matrix metalloproteinase activity and immunohistochemical profile of matrix metalloproteinase-2 and -9 and tissue inhibitor of metalloproteinase-1 during human dermal wound healing. Wound Repair Regen 12:295-304

89. Smith AR, Hosker GL, Warrell DW (1989) The role of partial denervation of the pelvic floor in the aetiology of genitourinary prolapse and stress incontinence of urine. A neurophysiological study. Br J Obstet Gynaecol 96:24-28 
90. Allen RE, Hosker GL, Smith AR, Warrell DW (1990) Pelvic floor damage and childbirth: a neurophysiological study. Br J Obstet Gynaecol 97:770-779

91. Ashton-Miller JA, Delancey JO (2007) Functional anatomy of the female pelvic floor. Ann N Y Acad Sci 1101:266-296

92. Meyer S, Schreyer A, De Grandi P, Hohlfeld P (1998) The effects of birth on urinary continence mechanisms and other pelvic-floor characteristics. Obstet Gynecol 92:613-618

93. Cannon TW, Lee JY, Somogyi G, Pruchnic R, Smith CP, Huard J et al (2003) Improved sphincter contractility after allogenic muscle-derived progenitor cell injection into the denervated rat urethra. Urology 62:958-963

94. Strasser H, Marksteiner R, Margreiter E, Pinggera GM, Mitterberger M, Fritsch $\mathrm{H}$ et al (2004) Stem cell therapy for urinary incontinence. Urologe A 43:1237-1241

95. Strasser H, Marksteiner R, Margreiter E, Pinggera GM, Mitterberger M, Frauscher F et al (2007) Autologous myoblasts and fibroblasts versus collagen for treatment of stress urinary incontinence in women: a randomised controlled trial. Lancet 369:2179-2186

96. Liapis A, Bakas P, Pafiti A, Frangos-Plemenos M, Arnoyannaki N, Creatsas G (2001) Changes of collagen type III in female patients with genuine stress incontinence and pelvic floor prolapse. Eur J Obstet Gynecol Reprod Biol 97:76-79

97. Goepel C, Hefler L, Methfessel HD, Koelbl H (2003) Periurethral connective tissue status of postmenopausal women with genital prolapse with and without stress incontinence. Acta Obstet Gynecol Scand 82:659-664

98. Klutke J, Ji Q, Campeau J, Starcher B, Felix JC, Stanczyk FZ et al (2008) Decreased endopelvic fascia elastin content in uterine prolapse. Acta Obstet Gynecol Scand 87:111-115

99. Lin SY, Tee YT, Ng SC, Chang H, Lin P, Chen GD (2007) Changes in the extracellular matrix in the anterior vagina of women with or without prolapse. Int Urogynecol J Pelvic Floor Dysfunct 18:43-48 